\title{
Application of Wild Yeast (Saccharomyces cerevisiae) Isolates from Palm Wine and Honey in Baking of Cassava/Wheat Composite Bread
}

\author{
James Bitrus, Onyetugo C. Amadi*, Tochukwu N. Nwagu, Chukwudi I. Nnamchi, Anene N. Moneke \\ Bioprocess and Fermentation Unit, Department of Microbiology, University of Nigeria, Nsukka, Nigeria \\ Email: *chioma.amadi@unn.edu.ng
}

How to cite this paper: Bitrus, J., Amadi, O.C., Nwagu, T.N., Nnamchi, C.I. and Moneke, A.N. (2020) Application of Wild Yeast (Saccharomyces cerevisiae) Isolates from Palm Wine and Honey in Baking of Cassava/Wheat Composite Bread. Food and Nutrition Sciences, 11, 695-711.

https://doi.org/10.4236/fns.2020.117050

Received: May 8, 2020

Accepted: July 14, 2020

Published: July 17, 2020

Copyright $\odot 2020$ by author(s) and Scientific Research Publishing Inc. This work is licensed under the Creative Commons Attribution International License (CC BY 4.0).

http://creativecommons.org/licenses/by/4.0/

(c) (i) Open Access

\begin{abstract}
Saccharomyces cerevisiae (baker's yeast) and wheat flour are the conventional raw materials used in baking of bread. Wheat flour is preferred due to gluten proteins providing bread elasticity. Interest is shown in using flours from cassava mainly due to economic and health reasons. Cassava does not have gluten protein required for bread elasticity. A different type of yeast would be required to bake bread using cassava flour. We investigated the use of composite (cassava/wheat) flour technology for bread baking. We also isolated yeast strains from palm wine (SPW) and honey (SH) using enriched media and evaluated their ability to produce acceptable cassava/wheat composite flour bread. Total of six yeast (3 each for palm wine and honey) strains identified as Saccharomyces cerevisiae were isolated. Two strains designated SPW and SH were selected and used for bread production. A commercial yeast strain (CY) was used as control. The major interest in this study included aroma, colour, taste, crust/texture, pore size, loaf weight and volume. Yeast concentration-1\% - 3\%, and flour composite combinations of $90 \%$ wheat $/ 10 \%$ cassava, $80 \%$ wheat $/ 20 \%$ cassava, and $70 \%$ wheat $/ 30 \%$ cassava were studied. The control was $100 \%$ wheat flour. Bread made from 90W:10C and 80W:20C compared favourably with bread made from 100\% wheat flour. Loaf volumes were: SPW $\left(850 \mathrm{~cm}^{3}\right), \mathrm{CY}\left(760 \mathrm{~cm}^{3}\right)$ and SH $(570$ $\mathrm{cm}^{3}$ ), whilst loaf weights were: $243 \mathrm{~g}$ for SPW, $260 \mathrm{~g}$ for CY and 298 for SH. Pore size estimations were: SPW loaf porosity (0.765), CY (0.740) and SH (0.655). Yeast concentrations of $2.5 \%$ performed best when SPW was used to produce bread from 70W:30C composite loaf. SPW also displayed combined role of gas production, aroma and flavor development in wheat/cassava composite bread. Mean performance of $\mathrm{CY}, \mathrm{SH}$ and SPW on sensory parameters of bread produced, varied significantly $(\mathrm{p}<0.05)$. Preference for aroma, colour, taste, crust/texture and general acceptability was in the order of SPW $>$
\end{abstract}


$\mathrm{CY}>\mathrm{SH}$.

\section{Keywords}

Saccharomyces cerevisiae, Cassava, Wheat, Aroma, Flavour

\section{Introduction}

Yeasts are ubiquitous, unicellular Fungi, that have the ability to ferment sugars into alcohol and carbon dioxide [1] and therefore used as leavening agent in baked products. The role of yeasts in the fermentation of sugars into alcohol and carbon dioxide has been exploited for decades by food and alcoholic beverage industries for the production of bread, beer, spirits, cider and wine. The main yeast strains used in bread making are from the $\mathcal{S}$. cerevisiae species [1] [2]. This is because they combine a number of pleasant characteristics like efficient and complete fermentation of high-sugar media, absence of toxin production, adequate gas production to ensure a uniform dough leavening, tolerance to a wide range of $\mathrm{pH}$, temperature, salt/sugar concentrations, as well as formation of desirable aroma and flavour compounds [3] [4] [5]. Recently bread aroma has gained more attention and recognition as an essential parameter in bread quality [6] [7]. In fermentation yeast produces mainly carbon dioxide, but the function of yeast goes beyond gas production in addition to the production of ethanol and other secondary metabolites, which have an impact on the final product quality, yeast affects the volume, structure, flavour, colour and shelf life of fermented product [2] [8]. Through the production of secondary metabolites via different metabolic pathways, yeast influences flavour, aroma, colour and shelf-life by producing precursors such as esters, aldehydes, ketones, carbohydrates, amino acids glycerol and acids. All these metabolic products demonstrate the important role of yeast in bread making and close connection between yeast addition and the final bread quality.

The growing interest in traditional and artisanal products, as well as the demand for products with distinctive aroma profiles is leading to a renewed interest in search for novel strains with relevant properties. Nowadays, bakers mainly use different flour additives such as enzymes (amylases, hemicellulases, and proteases) to change and improve dough properties and/or bread quality. Another strategy is to use novel industrial Baker's yeast capable of baking quality bread. At the moment no genetically modified yeast strain is used in the baking industry, in spite of the fact that studies have demonstrated that recombinant DNA technology is a possibility to obtain improved strains suitable for baking. Even where such yeast exists, majority of world will reject the use of genetically modified microorganisms in the production of food. This leaves room for other strategies to improve bread quality. Presently, very small number of genetically related and domesticated Saccharomyces strains are used in baking industry. 
Particularly the bakery strains in use are thought to have originated from sexual crosses between a single ale and wine strain [8]. Although the use of homogenic group of $S$. cerevisiae yeasts for the leavening of bread dough has enhanced, consistency, speed and overall quality of dough fermentations there is limitation in the sensorial complexity of the end product [9] [10]. The potential of the natural yeast diversity is underexplored [4] [11]. Yeast can be isolated from various environment especially sugary foods and alcoholic beverages such as honey, palm wine and grape vines [12]. Fermented beverages are well known to harbor heterogeneous microfloras including yeasts.

Bread is a staple food and a highly consumed non-indigenous food product after rice in Nigeria [13]. The demand for bread product in Nigeria has been on the increase. Bread products with varying sizes and shapes packaged in different materials are sold in both urban and rural regions of the nation [14]. Bread is produced traditionally by a mixture of wheat flour, yeast (Sacchromyces cerevisiae), salt and water and plays a role in providing adequate energy and other nutrients like proteins, B-vitamins, vitamin E and minerals. As long as the demand for bread increases due to increase in population and urbanization, the cost of raw materials such as wheat flour also becomes very expensive [15].

Bread as is known to most Nigerians is made from $100 \%$ wheat flour. The unique bread making properties of wheat flour is associated with the ability of its gluten proteins to form a viscoelastic network when mixed with water [16]. When wheat flour is mixed with water, a complex gluten protein is formed. The gluten gives wheat dough the elastic structure that allows it to be worked in variety of ways, allowing retention of bubbles of gas in an intact structure, resulting in a sponge-like texture [17]. To reduce the nation's expense on wheat importation, save foreign exchange and obtain a broad utilization of the increasingly produced cassava roots, the Federal Government mandated the use of composite cassava-wheat flour for baking by adding minimum of $10 \%$ cassava flour to wheat for a start [13]. This has generated a growing interest in using composite flour for bread making owing to some economic, social and health reasons. However, the partial substitution of wheat flour by other flour types presents considerable technological difficulties; their proteins lack the ability to form the necessary gluten network for holding the gas produced during fermentation, the dough formed is more difficult to handle, bread has poor loaf volume, poor crumb softness, and impaired sensory qualities such as aroma, taste, colour, texture, crust general acceptability and others [18].

Baker's yeast (Saccharomyces cerevisae) is not adapted for composite bread making, as such might not be suitable for baking bread using composite flours. In this regard, sourcing novel yeast strains for use in baking bread using composite flour would meet the growing demand for bread in Nigeria. Palm wine, the fermented sap of oil palm tree (Elaeis guineensis) is a popular beverage in Nigeria. It is very rich in micro-organisms with Saccharomyces cerevisiae being the predominant species. A lot of studies have been carried out on palm wine by 
many Nigerian scholars [19] [20] [21], exploring both biological and economic aspect of the species found in palm wine. Furthermore palm wine is known for specific characteristic aroma and flavour [22] [23]. Again, honey is also a good habitat for yeast including the $S$. cerevisae species. The aim of the study was two-fold: 1) to obtain novel yeast isolates from palm wine and honey and 2) to use the yeast isolates from these sources in baking bread using different composites of wheat/cassava flours. The overall quality of the bread was also assessed including sensory evaluation.

\section{Materials and Methods}

Fresh palm wine sample was collected in clean $1 \mathrm{~L}$ container from palm wine tappers within $30-60 \mathrm{~min}$ of tapping. The sample was immediately transported to the laboratory for analysis in iced cooler. Sweet cassava variety (Manihot esculenta) and honey samples were obtained from Enugu Ezike in Igbo-Eze North Local Government Area, Enugu State, Nigeria. Wheat flour, baking yeast, salt, sugar, fat, and milk were purchased from Nsukka main market, Nsukka Local Government Area, Enugu State, Nigeria.

\section{Isolation and Screening for Saccharomyces Strains}

Yeast were isolated using YPDA (10 g/L yeast extract; $20 \mathrm{~g} / \mathrm{L}$ glucose; $15 \mathrm{~g} / \mathrm{L}$ agar; $20 \mathrm{~g} / \mathrm{L}$ peptone) supplemented with chloramphenicol $0.05 \mathrm{mg} / \mathrm{ml}, 8 \%$ ethanol and $1 \mathrm{ml}$ of $1 \mathrm{M} \mathrm{HCL}$ incubated at $30^{\circ} \mathrm{C} \pm 2^{\circ} \mathrm{C}$ for $48-72 \mathrm{~h} \mathrm{[24]} \mathrm{[25].}$

\section{Morphological Identification}

Identification of yeast was done by standard morphological and physiological tests as described by [26]. Yeast morphology under magnification by microscope was noted and colony appearances on agar plates were observed for surface appearance, margin, colour and shape. Results were compared with standard yeast morphology as described by [26].

\section{Sugar Fermentation Potential}

Sugar fermentative ability of the yeast isolates as described by [27] was determined using the following sugars: glucose, sucrose, lactose, galactose, maltose, xylose and raffinose. The basal medium contained $0.5 \%(\mathrm{w} / \mathrm{v})$ yeast extract, $0.75 \%(\mathrm{w} / \mathrm{v})$ peptone and bromothymol blue indicator. The medium was dispensed into test tubes containing inverted durham tubes, cotton-plugged, sterilized at $121^{\circ} \mathrm{C}$ for 15 minutes and allowed to cool to room temperature. An aliquot of $2.0 \mathrm{ml}$ filter sterilized sugar solution $(6 \% \mathrm{w} / \mathrm{v})$ was added aseptically to the test tubes and inoculated with $0.1 \mathrm{ml}$ of 24 hours yeast suspension. The un-inoculated tube was used as control for each sugar substrate and the growth medium tubes were incubated at room temperature $\left(30^{\circ} \mathrm{C}\right)$ for 48 hours. Thus, gas production and medium colour change indicated the fermentative activity of the yeast strains.

\section{Nitrogen Assimilation}

The nitrate assimilation was analyzed using basal medium comprising of yeast carbon base $(117 \% \mathrm{w} / \mathrm{v})$ and $0.78 \% \mathrm{w} / \mathrm{v}$ nitrogen source. Nitrogen assimilation 
medium which comprised of $0.5 \mathrm{ml}$ of the basal medium and $4.5 \mathrm{ml}$ of sterile distilled water was mixed thoroughly, inoculated with $0.1 \mathrm{ml}$ of 24 hours old washed yeast culture and incubated at room temperature $\left(30^{\circ} \mathrm{C}\right)$ for seven days. Turbidity or presence of sediment in the medium after 3 to 7 days indicated the ability of the yeast to utilize nitrate or lysine as its nitrogen source as described by [28].

\section{Propagation of the Yeast Isolates}

The yeasts isolated were cultivated individually at $30^{\circ} \mathrm{C}$ in sterilized peptone broth medium containing $2 \%(\mathrm{w} / \mathrm{v})$ glucose and lactic acid at concentration of $0.2 \%(\mathrm{v} / \mathrm{v})$ in 1.0 litre conical flask equipped with air lock [14]. The set up was agitated and yeast cells were harvested at early stationary phase. To obtain different concentrations $(1 \%-3 \%)$ cell density was measured using a spectrophotometer based on the optical density measured at $600 \mathrm{~nm}$. The commercial brand of baker's yeast preserved on a slope was propagated on agar plates and used to prepare a suspension.

\section{Processing of Cassava Roots into Flour}

The fresh cassava roots variety (Manihot esculenta) was processed into flour. The cassava roots were peeled manually with a sharp knife, washed and grated in a locally fabricated grater [29]. The grater was made of a flat galvanized sheet punctured with holes with a big nail with opening of $0.7 \mathrm{~cm}$ diameter and fixed round a drum-like plank. The washed cassava roots were held by hand and over the rotating drum with extreme care that fingers and palm are not bruised [30]. They were then packed into Hessian sack and dewatered by pressing. The dewatered lumps were pulverized with hands and sifted on a local raffia made sieve mounted on a rectangular wooden frame to remove the fibres. The sifted cassava meal obtained was allowed to dry in a cabinet dryer. The dried meal was milled and sieved with a fine mesh $(200 \mu \mathrm{m})$ and later packed in a polyethylene bag and kept under dry condition until ready for further analysis.

\section{Microscopic Examination of Flours of the Flours}

Microscopic examination of flours was carried out to visualise the starch granules using a Leica Binocular Light Microscope with cross polarisation at 100x and 400× magnifications [31].

\section{Bread Production Process}

The flour blend formulation (composite) was used to produce bread using the straight dough method described by [32]. The baking formula; flour $56 \%$, water $36 \%$, sugar $3.4 \%$, fat $1.6 \%$, salt $1 \%$, yeast $1 \%$ and milk $1 \%$ as described by [33] was used. All ingredients apart from water were initially dry mixed and later water was mixed with the original dry mix sample until soft dough that can easily be handled was produced. The concentration of yeasts was varied from $1 \%$, $1.5 \%, 2 \%, 2.5 \%$ and $3 \%$. The whole dough mass was kneaded using a kneading machine and divided into equal sizes of $100 \mathrm{~g}$ and then manually moulded into cylindrical shape, and placed in a baking pan. Dough proofing was carried out at room temperature before baking. The dough was baked at $230^{\circ} \mathrm{C}$ for 30 minutes. Bread produced was allowed to cool until was ready for analysis [34]. 


\section{Loaf Weight and Volume Measurement}

The weight of bread was determined after cooling using a digital balance. Loaf volume was determined by grain displacement method as described by [35]. A baking pan was filled with clean cereal (rice) grain and levelled out. The grain was poured out and the bread was put into the pan. The pan was refilled with the grain and levelled out. The excess grains were taken as the volume of the loaf.

\section{Organoleptic Analysis}

The sensory evaluation of bread samples was carried out for consumer acceptance and preference using 10 judges (staff of Home Science, Nutrition and Dietetics Department and Food Science and Technology Department, University of Nigeria, Nsukka), using a Nine (9) point Hedonic scale (1 and 9 representing "extremely dislike" and "extremely like", respectively). The qualities assessed include aroma, colour, taste, crust/texture and general acceptability. The data collected was analyzed statistically using analysis of variance (ANOVA).

\section{Pore Size Estimation}

The pore size of loaf sample was determined by taking the difference between the volume of bulk solids $\left(V_{b s}\right)$ and true solid volume $\left(V_{t s}\right)$ [36]. The bulk volume of bread, $V_{b s}$ was measured using the rapeseed displacement method while volume of true solids, $V_{t s}$ was determined by rapeseed displacement method after mechanically compacting the bread to exclude all the pores [37] [38].

In the rapeseed displacement method, first the volume of rapeseeds was determined by filling a glass container of known volume uniformly with rapeseeds through tapping and smoothing the surface with a ruler. Then, the bread sample and rapeseeds were placed together into the container. The container was again tapped and the surface was smoothed with a ruler. Excess rapeseed was taken as the bulk solid volume, $V_{b s}$ or $V_{t s}$ as the case may be. Therefore,

$$
\text { Total porosity }=\frac{v_{b s}-v_{t s}}{v_{b s}}
$$

\section{Results}

Yeast isolates from palm wine and honey were characterized using YPDA containing 1M HCL and 8\% ethanol which ensured tentative selection of Saccharomyces cerevisiae strains. Six isolates were isolated, screened and identified based on morphological, cultural and physiological characteristics. The six isolates were designated $\mathrm{SPW}_{1}, \mathrm{SPW}_{2}$ and $\mathrm{SPW}_{3}$ from palm wine and $\mathrm{SH}_{1}, \mathrm{SH}_{2}$ and $\mathrm{SH}_{3}$ from honey samples. They were found to be identical with the standard strain of Saccharomyces cerevisiae characteristically as they did not assimilate Lysine and nitrate as nitrogen source (Yarrow, 1998) or ferment lactose and xylose. Further test was the ability of the isolates to ferment glucose, sucrose, maltose, galactose, raffinose with production of acid and gas and confirmed the isolates Saccharomyces cerevisiae. Gas production and medium colour change (acid production) are indicative of fermentative ability [27], while morphological and cultural attributes of the yeast strains were also in line as described by [26]. The most po- 
tent isolates were $\mathrm{SPW}_{1}$ (designated as $\mathrm{SPW}$ ) from palm wine and $\mathrm{SH}_{3}$ (designated as $\mathrm{SH}$ ) from honey and a commercial baker's yeast strain, CY (control for comparison) obtained from the market propagated and preserved on slants were used for bread production. Percentage, wheat-cassava flour combinations are shown in Table 1.

Figure 1 shows the microscopic view of yeast cells (Saccharomyces cerevisiae) isolated from palm (SPW) and honey (SH) yeast and commercial (CY) samples stained with lactophenol and viewed microrscopically using $\times 40$ magnification. SPW was oval/spherical in shape; some were budded while others were not while SH had mostly spherical shape some were budded while others were not.

Microscopic results of the cassava flour (Figure 2(a)) indicated the presence of clusters of similar sizes of starch granules while the starch granules of the wheat flour (Figure 2(b)) showed the presence of larger and smaller granules. Agu [39] observed similar starch granule distribution in edible yam starch which is a tuber as is the case with cassava. Similar observations were also found in starch granule distribution from "Aduegbe" (a wild tuber) [31]. This suggests that such cluster of small starch granule size is characteristic of starches from tubers, this is contrary to the observation found in the the starch granule distribution from wheat (cereal) composed of smaller and lager starch granules [40].

Figure 3 shows the sliced portions of the bread baked with 100\% wheat but with Saccharomyces strains SH (Figure 3(a)), CY (Figure 3(b)) and SPW (Figure $3(\mathrm{c})$ ). Sliced portions of bread baked with SPW had higher loaf volume and less dense than bread baked with CY and SH. The sample of bread baked with $80 \%$ wheat $/ 20 \%$ cassava composite using varying concentration $(1 \%-3 \%)$ of $\mathrm{SH}, \mathrm{CY}$ and SPW is shown in Figure 4(a) for SH, Figure 4(b) for CY and Figure 4(c) for SPW yeasts. Results (Figures 4(a)-(c)) show that SPW produced bread that had a better loaf appearance (golden brown colour) and volume when baked under similar conditions. Bread baked with strain CY showed similar appearance to SPW. Lower loaf volume and poorer loaf colour and less volume were obtained from bread baked with strain SH. Figure 5 shows that the bread baked with $100 \%$ cassava using the same varying concentration $(1 \%-3 \%)$ of yeast was very poor when compared with bread baked with $80 \%$ wheat $/ 20 \%$ cassava composite using similar yeast concentration shown in Figure 4(b).

Figure 6 compares different flour composition and different yeast strains on the volume of loaf produced. Highest loaf volume was recorded in loaf made with SPW $\left(850 \mathrm{~cm}^{3}\right)$ followed by loaf made with CY $\left(760 \mathrm{~cm}^{3}\right)$ while loaf made with $\mathrm{SH}\left(570 \mathrm{~cm}^{3}\right)$ had the least. Bread sample produced from $90 \mathrm{~W}: 10 \mathrm{C}$ flour composite had volume not significantly different from those produced from 100W flours. Generally least volume was observed with bread samples produced from 70W:30C composite flour. There was variation in the performance of the different yeast concentrations. However an interesting thing to note is the performance of yeast concentration $2.5 \%$ SPW, which showed higher loaf volume for $90 \mathrm{~W}: 10 \mathrm{C}, 80 \mathrm{~W}: 20 \mathrm{C}$ and $70 \mathrm{~W}: 30 \mathrm{C}$ composite. 
Table 1. Percentage composition of wheat and cassava flour.

\begin{tabular}{ccc}
\hline Samples & \% Wheat flour & \% Cassava flour \\
\hline $90 \mathrm{~W}: 10 \mathrm{C}$ & 90 & 10 \\
80W:20C & 80 & 20 \\
70W:30C & 70 & 30 \\
100W & 100 & 0 \\
\hline
\end{tabular}

Keys: $\mathrm{W}=$ Wheat flour, $\mathrm{C}=$ Cassava flour.

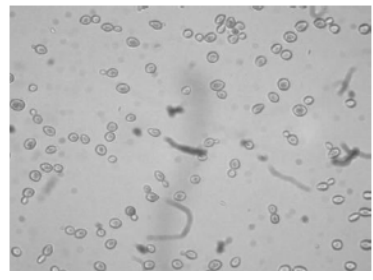

(a)

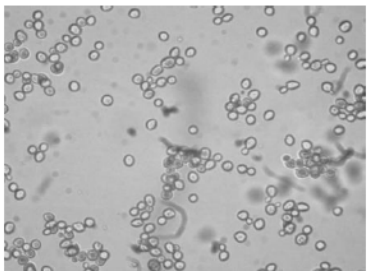

(b)

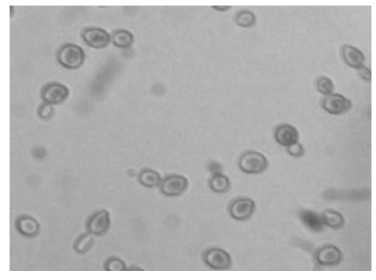

(c)

Figure 1. Microscopic view of yeast cells (Saccharomyces cerevisiae) from (a) palm wine (SPW), (b) honey (SH) and (c) commercial yeast (CY).

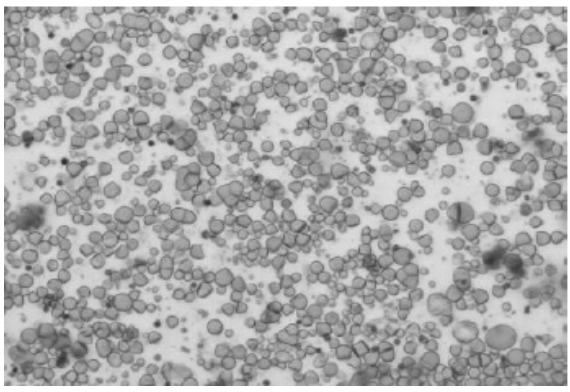

(a)

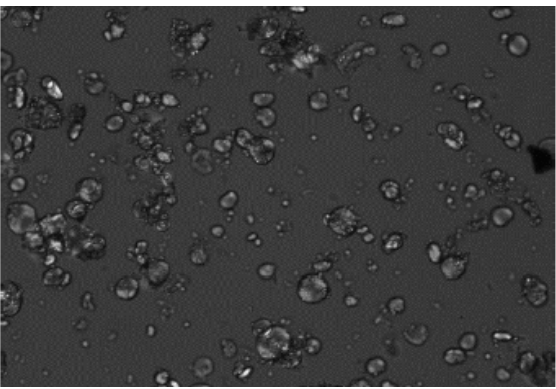

(b)

Figure 2. Photomicrographs of (a) cassava and (b) wheat flours starch granules.

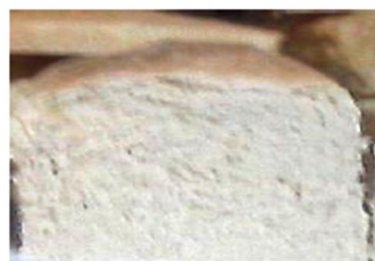

(a)

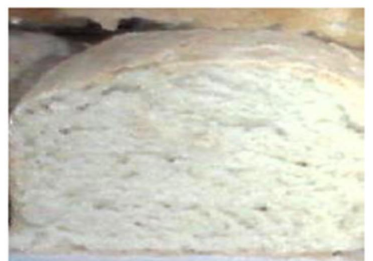

(b)

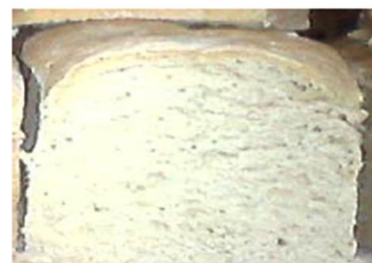

(c)

Figure 3. Sliced bread samples produced using $100 \%$ wheat flour (control), but with different yeasts: SH (a), CY (b) SPW (c).
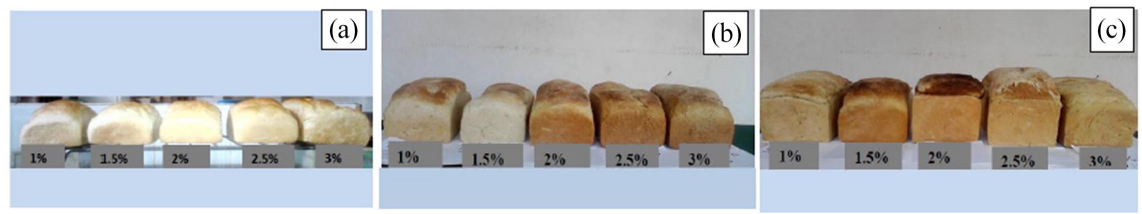

Figure 4. Bread samples produced using $80 \%$ wheat flour, $20 \%$ cassava flour but with different yeasts: $\mathrm{SH}(\mathrm{a}), \mathrm{CY}$ (b) SPW (c). 


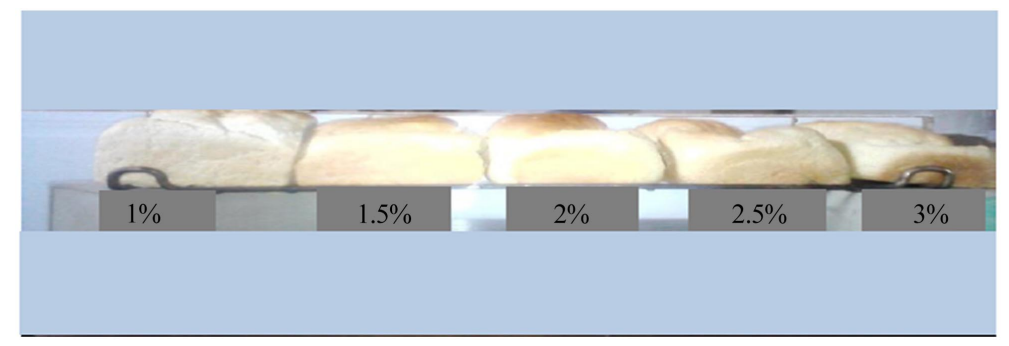

Figure 5. Bread samples produced using $100 \%$ cassava flour and varying yeast $(\mathrm{CY})$ concentration.

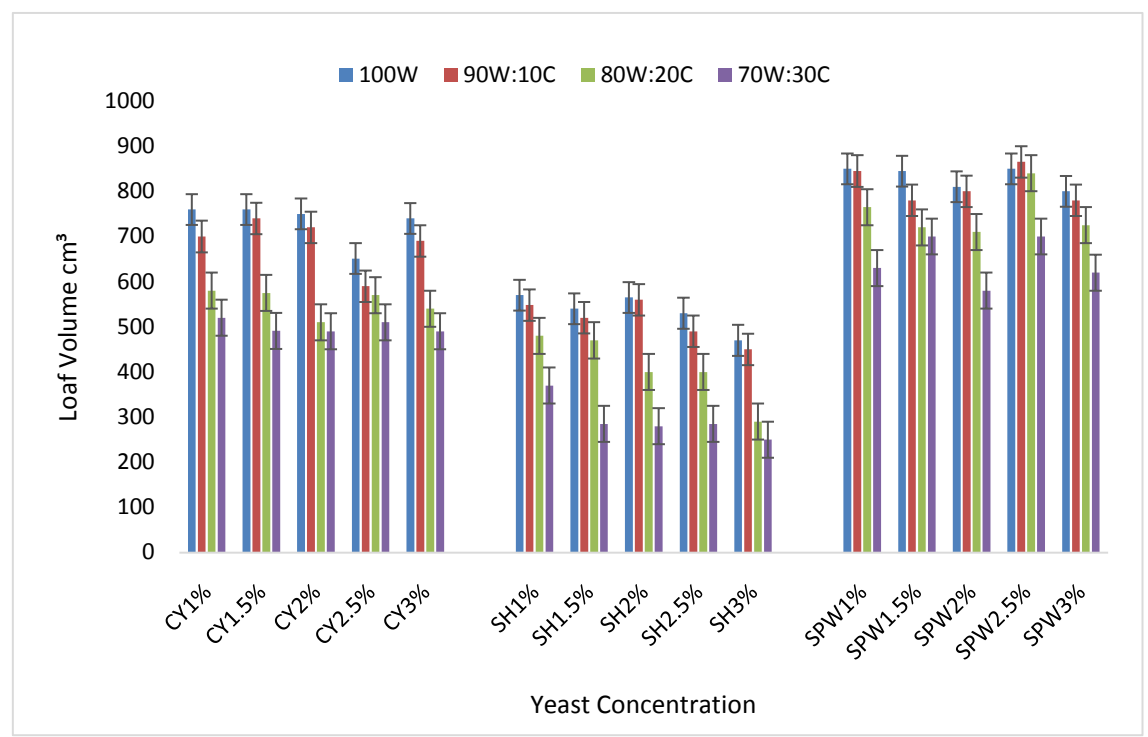

Figure 6. Comparison of flour composition on the volume of loaf produced with (CY), (SH) and (SPW).

The effect of composite flour and different yeast isolates (CY, SH, SPW) on loaf weight is shown in Figure 7. The result revealed that loaf produced with $\mathrm{SH}$ had the highest loaf weight across all composite combinations with (298.1 g) followed by CY with loaf weight of $(260 \mathrm{~g})$ and the least was SPW with loaf weight of $(243 \mathrm{~g})$. However the $2.5 \% \mathrm{SPW}$ yeast concentration appeared to have the least loaf weight even for $70 \mathrm{~W}: 30 \mathrm{C}$ composite.

Mean performance of CY, SH and SPW on the sensory parameters of bread is shown in (Table 2). Sensory scores of aroma showed that mean performance of all the yeasts differed significantly $(\mathrm{p}<0.05)$. Mean preference for aroma was higher in bread samples made with SPW (7.22) followed by CY (6.80) while SH had the lowest preference (6.41). Mean scores of color showed that there was no significant difference $(\mathrm{p}<0.05)$ between CY and SH while SPW differed significantly $(\mathrm{p}<0.05)$. Preference for color was higher in bread made with SPW (6.48) while $\mathrm{CY}$ and SH had the least. Sensory evaluation of taste indicated that there was no significant difference $(\mathrm{p}<0.05)$ between bread made with CY and SPW while that made with SH differed significantly $(\mathrm{p}<0.05)$. Higher preference for taste was observed in bread made with CY and SPW. With respect to sensory scores of crust/texture, there was significant difference $(\mathrm{p}<0.05)$ among yeasts. 
Higher preference for crust was observed in bread made with SPW (5.97) followed by CY (5.96) while SH had lower preference (5.30). Mean scores of acceptability revealed that there was significant difference $(\mathrm{p}<0.05)$, SPW showed higher preference (6.10) followed by CY (5.81) while SH had the lowest (5.36).

Table 3 shows the mean performance of flour composition on the sensory attributes of bread produced. It was observed from the results that sensory scores of aroma, color, taste, crust/texture and general acceptance differed significantly at $0.05 \%$ level. Bread samples made from $100 \%$ wheat (100W) flour had preference for aroma with mean score of 8.20 , color with mean score of 7.00 , taste with mean score of 7.10, crust/texture with mean score of 7.23 and general acceptability with mean score of 7.30 while bread samples made with $90 \mathrm{~W}: 10 \mathrm{C}$ composite flour had mean scores of 8.21, 6.97, 7.13, 6.97, and 7.33 for aroma, color, taste, crust/texture and general acceptability respectively. Bread samples made from 80W:20C flour composite had lower mean score of 6.40, 5.97, 5.58, 5.31 and 5.26 for aroma, color, taste, crust/texture and general acceptability respectively. Composite flour of 70W:30C had the least in terms of preference for aroma, color, taste, crust/texture and general acceptability with mean scores of 5.44, 5.20, 4.28, 4.40 and 4.37 respectively.

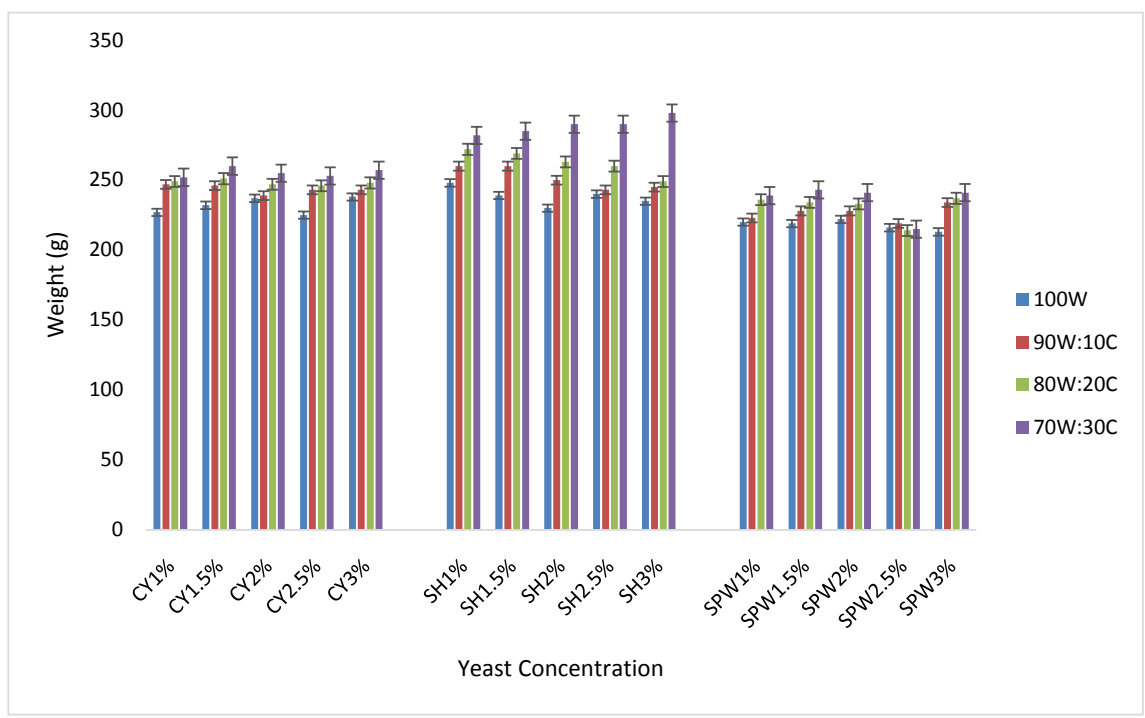

Figure 7. Comparison of different flour composition on the weight of loaf produced with (CY), (SH) (SPW).

Table 2. Mean scores (performance) of the yeasts on sensory parameters of loaf produced.

\begin{tabular}{cccccc}
\hline Yeast & Aroma & Color & Taste & Crust/Texture & Acceptability \\
\hline CY & $6.80^{\mathrm{a}}$ & $6.08^{\mathrm{a}}$ & $6.07^{\mathrm{a}}$ & $5.96^{\mathrm{a}}$ & $5.81^{\mathrm{b}}$ \\
SH & $6.41^{\mathrm{b}}$ & $5.99^{\mathrm{a}}$ & $5.56^{\mathrm{b}}$ & $5.30^{\mathrm{b}}$ & $5.36^{\mathrm{a}}$ \\
SPW & $7.22^{\mathrm{c}}$ & $6.48^{\mathrm{b}}$ & $6.07^{\mathrm{a}}$ & $5.97^{\mathrm{a}}$ & $6.10^{\mathrm{c}}$ \\
LSD & 0.29 & 0.19 & 0.21 & 0.30 & 0.22 \\
\hline
\end{tabular}

Means with different superscripts letters within the column differed significantly at $\mathrm{p}<0.05$. 
Table 3. Mean scores (performance) of flour composition on the sensory parameters of loaf produced.

\begin{tabular}{cccccc}
\hline Flour & Aroma & Color & Taste & Crust/Texture & Acceptability \\
\hline $100 \mathrm{~W}$ & $8.20^{\mathrm{d}}$ & $7.00^{\mathrm{d}}$ & $7.10^{\mathrm{d}}$ & $7.23^{\mathrm{d}}$ & $7.30^{\mathrm{d}}$ \\
$90 \mathrm{~W}: 10 \mathrm{C}$ & $8.21^{\mathrm{a}}$ & $6.97^{\mathrm{a}}$ & $7.13^{\mathrm{a}}$ & $6.97^{\mathrm{a}}$ & $7.33^{\mathrm{a}}$ \\
$80 \mathrm{~W}: 20 \mathrm{C}$ & $6.34^{\mathrm{b}}$ & $5.97^{\mathrm{b}}$ & $5.58^{\mathrm{b}}$ & $5.31^{\mathrm{b}}$ & $5.26^{\mathrm{b}}$ \\
$70 \mathrm{~W}: 30 \mathrm{C}$ & $5.44^{\mathrm{c}}$ & $5.20^{\mathrm{c}}$ & $4.80^{\mathrm{c}}$ & $4.40 \mathrm{c}$ & $4.37^{\mathrm{c}}$ \\
LSD & 0.17 & 0.20 & 0.21 & 0.23 & 0.22 \\
\hline
\end{tabular}

Means with different superscripts letters within the column differed significantly at $\mathrm{p}<0.05$.

The mean scores of diferrent yeast concentration on the sensory properties of loaf produced are shown in Table 4. The mean scores of aroma, color, taste, crust/texture and general acceptability did not appear to differ significantly ( $\mathrm{p}<$ $0.05)$ in loaf produced at various yeast concentration $(1 \%, 1.5 \%, 2 \%, 2.5 \%$ and $3 \%$ ), there however, appeared to have slightly better performance with $2.5 \%$ yeast concentration.

Pore size estimation of some selected loaf is shown in Table 5 using the highest volume produced from different flour combinations $90 \mathrm{~W}: 10 \mathrm{C}, 80 \mathrm{~W}: 20 \mathrm{C}$, $70 \mathrm{~W}: 30 \mathrm{C}$ and $100 \mathrm{~W}$. The result revealed that loaf made with SPW had the highest total porosity of $0.765,0.767,0.762$ and 0.718 for $100 \mathrm{~W}, 90 \mathrm{~W}: 10 \mathrm{C}, 80 \mathrm{~W}: 20 \mathrm{C}$ and 70W:30C composite flours respectively followed by loaf made with CY with total porosity of $0.740,0.736,0.659$ and 0.623 for $100 \mathrm{~W}, 90 \mathrm{~W}: 10 \mathrm{C}, 80 \mathrm{~W}: 20 \mathrm{C}$, and 70W:30C composite flours respectively. Loaf made with $\mathrm{SH}_{3}$ had the least total porosity of $0.655,0.651,0.598$ and 0.495 for $100 \mathrm{~W}, 90 \mathrm{~W}: 10 \mathrm{C}, 80 \mathrm{~W}: 20 \mathrm{C}$ and 70W:30C composite flours respectively.

\section{Discussion}

Selective enrichment media was used to isolate and identify Saccharomyces cerevisiae strains from palm wine and honey used in composite bread making. Enrichment culturing is a reliable and frequently-used method for isolating microbes, including Saccharomyces, from natural environments [25] [41] [42] and enrichment culturing is widely used to isolate many of the model Saccharomyces strains in laboratory studies [41] [43] [44]. To isolate Saccharomyces from natural substrates, many investigations of wild Saccharomyces rely on enrichment culturing, mostly in high-sugar, acidic media [41] [45] [46] [47]. The explanations immediately above are the justification for our choice in selecting the yeast strains used in this study. The two strains selected for this study designated as Saccharomyces honey (SH) and Saccharomyces palm wine (SPW) showed great potential to produce bread when compared with the control commercial baker's yeast strain, (CY). They performed well like other Saccharomyces cerevisiae as leavening agent in baking bread by converting the fermentable sugars present in the dough into alcohol and carbon dioxide-a process of adding gas to the dough before or during baking to produce higher, more easily chewed bread [48] [49]. 
Table 4. Mean scores of different yeast concentration on the sensory parameters of loaf produced.

\begin{tabular}{cccccc}
\hline Yeast & Aroma & Color & Taste & Crust/Texture & Acceptability \\
\hline $1 \%$ & $6.72^{\mathrm{a}}$ & $6.22^{\mathrm{a}}$ & $5.93^{\mathrm{a}}$ & $5.80^{\mathrm{a}}$ & $5.72^{\mathrm{a}}$ \\
$1.5 \%$ & $6.85^{\mathrm{a}}$ & $6.18^{\mathrm{a}}$ & $5.90^{\mathrm{a}}$ & $5.60^{\mathrm{a}}$ & $5.68^{\mathrm{a}}$ \\
$2 \%$ & $6.81^{\mathrm{a}}$ & $6.10^{\mathrm{a}}$ & $6.04^{\mathrm{a}}$ & $5.79^{\mathrm{a}}$ & $5.80^{\mathrm{a}}$ \\
$2.5 \%$ & $6.95^{\mathrm{a}}$ & $6.24^{\mathrm{a}}$ & $6.05^{\mathrm{a}}$ & $5.77^{\mathrm{a}}$ & $5.86^{\mathrm{a}}$ \\
$3 \%$ & $6.76^{\mathrm{a}}$ & $6.28^{\mathrm{a}}$ & $5.85^{\mathrm{a}}$ & $5.72^{\mathrm{a}}$ & $5.70^{\mathrm{a}}$ \\
LSD & 0.25 & 0.25 & 0.26 & 0.23 & 0.27 \\
\hline
\end{tabular}

Means with different superscripts letters within the column differed significantly at $\mathrm{p}<0.05$.

Table 5. Pore size of loaf with highest volume produced from various flour compositions.

\begin{tabular}{ccccc}
\hline Yeast & Flour composition & & & \\
& $100 \mathrm{~W}$ & $90 \mathrm{~W}: 10 \mathrm{C}$ & $\mathbf{8 0 \mathrm { W } : 2 0 \mathrm { C }}$ & $\mathbf{7 0 W}: 30 \mathrm{C}$ \\
SPW & 0.764 & 0.767 & 0.763 & 0.718 \\
CY & 0.740 & 0.736 & 0.659 & 0.623 \\
SH & 0.655 & 0.651 & 0.598 & 0.495 \\
\hline
\end{tabular}

Comparison of the different yeast isolates ( $\mathrm{SH}, \mathrm{CY}, \mathrm{SPW}$ ) and flour composition (W90:10C, W80:20C, W70:30C, 100W) on loaf volume and weight revealed that loaf volume decreased as the level of substitution of cassava flour increased (Figure 6), but generally higher loaf volume was recorded in loaf made with SPW followed by loaf made with CY while loaf made with SH had the least. Although loaf volume decreased with increase in cassava flour, SPW $2.5 \%$ and $1.5 \%$ yeast concentration used in baking 70W:30C composite, showed improved loaf volume and lesser loaf weight, than the other composite combinations. These observations suggest that yeast strain as well as concentration used will influence loaf volume and loaf weight. Yeast type will also play important role in the quality of baked bread because SPW performed very well when compared with CY yeast. Similar observation was made by [14] who observed that yeast isolated from cassava performed favourably with commercial yeast when used for bread baking. On the contrary [16] [50] reported that when concentration of wheat flour in each successive sample was reduced, there was reduction in wheat gluten and thus a corresponding decrease in dough volume. Notwithstanding, the results obtained from this showed that the source of yeast (SPW Saccharomyces from palm wine) and concentration may have impacted on loaf volume and weight. Since loaf weight is basically the quantity of dough baked and the amount of moisture and carbon dioxide diffused out of the loaf during baking [13], good performance of SPW is indicative of its fermentative ability.

Mean performance of $\mathrm{CY}, \mathrm{SH}$ and SPW on the sensory parameters of bread produced (Table 2 ) showed that there was significant difference $(\mathrm{p}<0.05)$. Generally it was noted that SPW performed better in terms of sensory scores of aroma, 
colour, taste, crust and general acceptability followed by $\mathrm{CY}$ while $\mathrm{SH}$ was the least performing. This is an additional advantage in the exploitation of this isolate for food application. SPW was isolated from palm wine and palm wines are known for their distinct flavours, aroma (esters, carbonyls, alcohols and phenols), and alcohol content a combination of these properties may have enhanced the performance of SPW strain [22] [23].

The sensory properties of loaf of bread made from blends of wheat and cassava flours as well as the $100 \%$ wheat bread showed that all sensory scores of aroma, colour, taste, crust/texture and general acceptability differed significantly $(\mathrm{p}<0.05)$. It was observed that increase in the substitution of cassava flour in the dough was responsible for the change in the sensory properties of the bread. The inclusion of $10 \%$ cassava flour compared favourably with $100 \mathrm{~W}$ loaf. Bread samples containing $10 \%$ and $20 \%$ cassava flour were acceptable, judging by all parameters used. Although, the composite containing 30\% cassava was less accepted by the panellists, this is not surprising as the high content of cassava made binding of the dough difficult, thus affecting the overall quality of the product and thus its acceptability. However it is worthy of note that with the sensory parameter aroma in particular, $30 \%$ cassava which is (70W:30C) recorded some level of acceptability.

The mean performance of yeast concentration on the sensory attributes of bread showed that sensory scores of aroma, colour, taste, crust and general acceptability did not vary considerably. However $2.5 \%$ yeast concentration appeared slightly better, with respect to loaf volume and weight yeast concentration $2.5 \%$ displayed better outcome even with 70W:30C composite. Although this was not part of our study, it is worth mentioning that a study by [6] showed that with increasing yeast concentration, flavour components like 2-methyl-1-propanol, 2-phenylethanol, phenylacetaldehyde, 2,3-butanedione, ethyl acetate, ethyl 3methylbutanoate, ethyl hexanoate, ethyl octanoate and phenyl-ethyl acetate increase concomitantly. On the contrary [33] implied that variation of yeast concentration had no effect on the sensory parameters and that $1 \%$ yeast was a standard formula for baking bread.

The pore size estimation of loaf produced revealed that loaf produced with SPW had higher total porosity followed by those produced with CY while those produced with SH had the least. This suggests that gas produced by SPW during fermentation was higher than that produced by other yeasts. This is not surprising as the source of yeast (palm wine) may have influenced the outcome. [36] stated that pore size of bread relates to amount of gas evolution by the yeast during fermentation and the time needed for the outer region of the dough to develop some rigidity, so that sustained expansion can take place as opposed to the gas leaving the dough. Again loaf produced with 70W:30C composite flours using SPW displayed good porosity.

\section{Conclusion}

Yeast isolates from palm wine (SPW), honey (SH) and control commercial baker's 
yeast (CY) were used to bake bread using wheat/cassava flour. In general, our results showed that yeast isolate from palm wine SPW gave overall good results in terms of loaf quality (loaf volume, loaf weigh) as well sensory evaluation. Yeast isolate (SPW) from palm wine outperformed the commercial yeast (CY). SPW will find good application in reducing composite flour baking technological difficulties. Although composite flour containing $10 \%$ and $20 \%$ cassava inclusion compared favourably with the control (100\% wheat bread), a higher $30 \%$ cassava composite flour inclusion was also acceptable when baked with SPW and an increased cell concentration of $2.5 \%$. In the current global trend it is important to look inward for means to grow a nation's economy.

\section{Acknowledgements}

This paper is dedicated to the memory of James Bitrus, postgraduate student, Department of Microbiology, UNN. We also want to thank Prof R. C. Agu a visiting Professor in the Department of Microbiology, UNN for kind review of the manuscript.

\section{Conflicts of Interest}

The authors declare no conflicts of interest regarding the publication of this paper.

\section{References}

[1] Cauvain, S. and Young, L.S. (2007) Technology of Breadmakng. 2nd Edition, Springer, Berlin.

[2] Fleet, G.H. (2007) Yeasts in Foods and Beverages: Impact on Product Quality and Safety. Current Opinion in Biotechnology, 18, 170-175. https://doi.org/10.1016/j.copbio.2007.01.010

[3] Linko, Y.-Y., Javanainen, P. and Linko, S. (1997) Biotechnology of Bread Baking. Trends in Food Science \& Technology, 8, 339-344. https://doi.org/10.1016/S0924-2244(97)01066-2

[4] Steensels, J. and Verstrepen, K.J. (2014) Taming Wild Yeast: Potential of Conventional and Nonconventional Yeasts in Industrial Fermentations. Annual Review of Microbiology, 68, 61-80. https://doi.org/10.1146/annurev-micro-091213-113025

[5] Piškur, J., Rozpędowska, E., Polakova, S., Merico, A. and Compagno, C. (2006) How Did Saccharomyces Evolve to Become a Good Brewer? Trends in Genetics, 22, 183-186. https://doi.org/10.1016/j.tig.2006.02.002

[6] Birch, A.N., Petersen, M.A. and Hansen, Å.S. (2013) The Aroma Profile of Wheat Bread Crumb Influenced by Yeast Concentration and Fermentation Temperature. LWT-Food Science and Technology, 50, 480-488. https://doi.org/10.1016/j.lwt.2012.08.019

[7] Birch, A.N., Petersen, M.A. and Hansen, A.S. (2014) Aroma of Wheat Bread Crumb. Cereal Chemistry, 91, 105-114. https://doi.org/10.1094/CCHEM-06-13-0121-RW

[8] Randez-Gil, F., Corcoles-Saez, I. and Prieto, J.A. (2013) Genetic and Phenotypic Characteristics of Baker's Yeast: Relevance to Baking. Annual Review of Food Science and Technology, 4, 191-214. 
https://doi.org/10.1146/annurev-food-030212-182609

[9] Domizio, P., Lencioni, L., Ciani, M., Di Blasi, S., Pontremolesi, C. and Sabatelli, M. P. (2007) Spontaneous and Inoculated Yeast Populations Dynamics and Their Effect on Organoleptic Characters of Vinsanto Wine under Different Process Conditions. International Journal of Food Microbiology, 115, 281-289.

https://doi.org/10.1016/j.ijfoodmicro.2006.10.052

[10] Daenen, L., Sterckx, F., Delvaux, F.R., Verachtert, H. and Derdelinckx, G. (2008) Evaluation of the Glycoside Hydrolase Activity of a Brettanomyces Strain on Glycosides from Sour Cherry (Prunus cerasus L.) Used in the Production of Special Fruit Beers. FEMS Yeast Research, 8, 1103-1114. https://doi.org/10.1111/j.1567-1364.2008.00421.x

[11] Gallone, B., Steensels, J., Prahl, T., Soriaga, L., Saels, V., Herrera-Malaver, B., et al. (2016) Domestication and Divergence of Saccharomyces cerevisiae Beer Yeasts. Cell, 166, 1397-1410. https://doi.org/10.1016/j.cell.2016.08.020

[12] Legras, J.-L., Merdinoglu, D., Cornuet, J.-M. and Karst, F. (2007) Bread, Beer and Wine: Saccharomyces cerevisiae Diversity Reflects Human History. Molecular Ecology, 16, 2091-2102. https://doi.org/10.1111/j.1365-294X.2007.03266.X

[13] Shittu, T.A., Raji, A.O. and Sanni, L.O. (2007) Bread from Composite Cassava-Wheat Flour: Effect of Baking Time and Temperature on Some Physical Properties of Bread Loaf. Food Research International, 40, 280-290.

https://doi.org/10.1016/j.foodres.2006.10.012

[14] Boboye, B. and Dayo-Owoyemi, I. (2009) Evaluation of Dough Sensory Properties Impacted by Yeasts Isolate from Cassava. Journal of Applied Sciences, 9, 771-776. https://doi.org/10.3923/jas.2009.771.776

[15] Okoye, J. I. and Okaka, J. C. (2009) Production and Evaluation of Protein Quality of Bread from Wheat/Cassava Flour Blends. Continental Journal of Food Science and Technology, 3, 1-7.

[16] Abaoba, O.O. and Obakpolor, E.A. (2010) The Leavening Ability of Bakers Yeast on Dough Prepared with Composite Flour (Wheat/Cassava). African Journal of Food Science, 4, 325-329.

[17] Schober, T.J., Messerschmidt, M., Bean, S.R., Park, S.-E. and Elke, K.A. (2005) Gluten-Free Bread from Sorghum: Quality Differences among Hybrids. Cereal Chemistry, 82, 394-404. https://doi.org/10.1094/CC-82-0394

[18] Mariotti, M., Lucisano, M. and Pagani, M.A. (2006) Development of a Baking Procedure for the Production of Oat-Supplemented Wheat Bread. International Journal of Food Science \& Technology, 41, 151-157. https://doi.org/10.1111/j.1365-2621.2006.01383.x

[19] Nwaiwu, O., Ibekwe, V.I., Amadi, E.S., Udebuani, A.C., Nwanebu, F.C., Oguoma, O.I. and Nnokwe, J.C. (2016) Evaluation of Fermentation Products of Palm Wine Yeasts and Role of Sacoglottis gabonensis Supplement on Products Abundance. Beverages, 2, 9. https://doi.org/10.3390/beverages2020009

[20] Ezeronye, O.U. and Legras, J.-L. (2009) Genetic Analysis of Saccharomyces cerevisiae Strains Isolated from Palm Wine in Eastern Nigeria. Comparison with Other African Strains. Journal of Applied Microbiology, 106, 1569-1578. https://doi.org/10.1111/j.1365-2672.2008.04118.x

[21] Agu, R.C., Okenchi, M.U., Ude, C.M., Onyia, A.I., Onwumelu, A.H. and Ajiwe, V.I.E. (1999) Fermentation Kinetic Studies of Nigerian Palm Wine-Elaeis guineensis and Raphia hookeri for Preservation by Bottling. Journal of Food Science and Technology, 36, 205-209. 
[22] Lasekan, O., Buettner, A. and Christlbauer, M. (2007) Investigation of Important Odorants of Palm Wine (Elaeis guineensis). Food Chemistry, 105, 15-23. https://doi.org/10.1016/j.foodchem.2006.12.052

[23] Uzochukwu, S.V.A., Balogh, E., Tucknott, O., Lewis, M.J. and Ngoddy, P.O. (1997) Volatiles of Palm Wine Using Solvent Extracts. Journal of Food Quality, 20, 483-494. https://doi.org/10.1111/j.1745-4557.1997.tb00489.x

[24] Kowallik, V. and Greig, D. (2016) A Systematic Forest Survey Showing an Association of Saccharomyces paradoxus with Oak Leaf Litter. Environmental Microbiology Reports, 8, 833-841. https://doi.org/10.1111/1758-2229.12446

[25] Schlegel, H.G. and Jannasch, H.W. (1967) Enrichment Cultures. Annual Reviews Microbiology, 21, 49-70. https://doi.org/10.1146/annurev.mi.21.100167.000405

[26] Kurtzman, C.P., Fell, J.W., Boekhout, T. and Robert, V. (2011) Methods for Isolation, Phenotypic Characterization and Maintenance of Yeast. In: Kurtzman, C.P., Fell, J.W and Teun, B., Eds., The Yeasts, a Taxanomy, 5th Edition, Elsevier Publishers, Amsterdam, 87-110. https://doi.org/10.1016/B978-0-444-52149-1.00007-0

[27] Jimoh, S.O., Ado, S.A., Baba, A.J. and CMZ, W. (2012) Osmotolerance and Fermentative Patern of Brewer's Yeast. Journal of Life Sciences and Medical Research, 2, 59-64.

[28] Yarrow, D. (1998) Methods for the Isolation, Maintenance and Identification of Yeast. In: Kurtzman, C.P. and Fell, J.W., Eds., The Yeasts, a Taxanomy Study, 4th Edition, Elsevier Publishers, Amsterdam, 77-100.

https://doi.org/10.1016/B978-044481312-1/50014-9

[29] Ogunbanwo, S.T., Adebayo, A.A., Ayodele, M.A., Okanlawon B.M. and Edema, M.O. (2008) Effects of Lactic Acid Bacteria and Saccharomyces cerevisiae Co-Cultures Used as Starters on the Nutritional Contents and Shelf Life of Cassava-Wheat Bread. Journal of Applied Biosciences, 12, 612-622.

[30] Agunbiade, S.O. (2001) Effect of Fermentation Period on the Physiochemical Properties of "Garri". Bioscience Research Commmunications, 13, 65-71.

[31] Agu, R.C., Walker, J.W., Okolo, B.N., Moneke, A.N., Amadi, O.C. and Eze, C.N. (2014) Bio-Ethanol Production from Dioscorea bulbifera Tuber (Local Name: "Aduegbe") - A Renewable Non-Cultivated, Non-Food, Waste Material in Nigeria. Journal of Solid Waste Technology and Management, 2, 152-159. https://doi.org/10.5276/JSWTM.2014.152

[32] Eggleston. G., Onwaka, P.E. and Ihedioha, O.D. (1992) Development and Evaluation of Products from Cassava Flour as a New Alternative to Wheat Bread. Journal of Science Food and Agriculture, 59, 377-385. https://doi.org/10.1002/jsfa.2740590315

[33] Ihekoronye, A.I. and Ngoddy, P.O. (1985) Integrated Food Science and Technology for the Tropics. 5th Edition, Macmillan Education, London.

[34] Oluwamukomi, M.O., Oluwalana, I.B. and Akinbowale, O.F. (2011) Physiochemical and Sensory Properties of Wheat/Cassava Composite Biscuit Enriched with Soy Flour. African Journal of Food Science, 5, 50-56.

[35] Ayo, J.A., et al. (2001) Production and Evaluation of Millet-Egg-Soybean Hull Composite Flour: A Weaning Food. American Journal of Food and Nutrition, 1, 7-13. https://doi.org/10.5251/ajfn.2011.1.1.7.13

[36] Ashim, K.D., Serpil, S., Gülüm, S. and Ozge, S.K. (2007) Porous Media Characterization of Breads Baked Using Novel Modes. Journal of Food Engineering, 79, 106-116. https://doi.org/10.1016/j.jfoodeng.2006.01.046 
[37] AACC (1988) Approved Methods of the AACC, AACC Method 74-09. American Association of Cereal Chemists, St. Paul.

[38] AACC Method 10-05.01 (2010) Guidelines for Measurement of Volume by Rapeseed Displacement.

[39] Agu, R.C. and Walker, J. (2012) Effect of Storage and Its Impact on Some Parameters Used in Assessing Distilling Wheat Cultivars. Technical Quarterly, 49, 19-24. https://doi.org/10.1094/TQ-49-1-0316-01

[40] Agu, R.C., Nnamchi, C.I., Moneke, A.N., Odibo, F.J.C., Nwanguma, B.C. and Okolo B.N. (2015) Influence of Added Commercial Enzyme Preparations and Mashing Temperature on Extract Recovery of Laboratory-Malted Nigerian-Grown Pearl Millet and Wheat. Technical Quarterly, 52, 124-131.

[41] Sniegowski, P.D., Dombrowski, P.G. and Fingerman, E. (2002) Saccharomyces cerevisiae and Saccharomyces paradoxus Coexist in a Natural Woodland Site in North America and Display Different Levels of Reproductive Isolation from European Conspecifics. FEMS Yeast Research, 1, 299-306. https://doi.org/10.1016/S1567-1356(01)00043-5

[42] Beijernick, M.W. (1961) Enrichment Culture 444 Studies with Urea Bacteria (T.D. Brock, Trans.) In: Brock, T.D., Ed., Milestones in Microbiology, Prentice-Hall International, London, 234-237.

[43] Johnson, L.J., Koufopanou, V., Goddard, M.R., Hetherington, R., Schafer, S.M. and Burt, A. (2004) Population Genetics of the Wild Yeast Saccharomyces paradoxus. Genetics, 166, 43-52. https://doi.org/10.1534/genetics.166.1.43

[44] Liti, G., Carter, D.M., Moses, A.M., Warringer, J., Parts, L., James, S.A. and Louis, E.J. (2009) Population Genomics of Domestic and Wild Yeasts. Nature, 458, 337-341. https://doi.org/10.1038/nature07743

[45] Charron, G., Leducq, J.B., Bertin, C., Dube, A.K. and Landry, C.R. (2014) Exploring the Northern Limit of the Distribution of Saccharomyces cerevisiae and Saccharomyces paradoxus in North America. FEMS Yeast Research, 14, 281-288. https://doi.org/10.1111/1567-1364.12100

[46] Robinson, H.A., Pinharanda, A. and Bensasson, D. (2016) Summer Temperature Can Predict the Distribution of Wild Yeast Populations. Ecology and Evolution, 6, 1236-1250. https://doi.org/10.1002/ece3.1919

[47] Sweeney, J.Y., Kuehne, H.A. and Sniegowski, P.D. (2004) Sympatric Natural Saccharomyces cerevisiae and $S$. paradoxus Populations Have Different Thermal Growth Profiles. FEMS Yeast Research, 4, 521-525. https://doi.org/10.1016/S1567-1356(03)00171-5

[48] Attfield, P.V. (1997) Stress Tolerance: The Key to Effective Strains of Industrial Baker's Yeast. National Biotechnology, 15, 1351-1357. https://doi.org/10.1038/nbt1297-1351

[49] Samuel, D. (2000) Brewing and Baking. Cambridge University Press, Cambridge, 537-576.

[50] Abdelghafor, R.F., Mustafa, A.I., Ibrahim, A.M. and Krishman, P.G. (2011) Quality of Bread from Composite Flour of Sorghum and Hard Winter Wheat. Advance Journal of Food Science and Technology, 3, 9-15. 